\title{
Students' Academic Procrastination in Doing Thesis
}

\author{
Erfan Ramadhani, Ramtia Darma Putri \\ Universitas PGRI Palembang, Indonesia. Korespondensi: Jl. A. Yani Lrg. Gotong Royong 9/10 Ulu \\ Palembang. Sumatera Selatan, Email : erfankonselor@gmail.com
}

\author{
Article Info \\ History of Article \\ Submited November 2019 \\ Accepted November 2019 \\ Published November 2019
}

\section{Key Word \\ Procrastination \\ Academic \\ College Student \\ Thesis}

\section{Kata Kunci}

Prokrastinasi

Akademik

Mahasiswa

Skripsi

\begin{abstract}
Academic procrastination is a delay in doing something, especially in working out demands as a student, both in working on college assignments and in doing the thesis. This study aims to reveal the level of academic procrastination of the teacher and faculty of education students of the PGRI University of Palembang, who are above the eighth semester. Students above the eighth semester are indicated to experience academic procrastination, as seen from the length of the study period. Furthermore, this study also aims to uncover the different levels of academic procrastination of male and female students in doing the thesis. This research is a comparative descriptive study which will later examine differences in the level of academic procrastination of male and female gender students using the t-test formula. This research was conducted in the faculty of education and education at the University of PGRI Palembang for three months. This research instrument uses a Likert scale model with five alternative answers. The data obtained were analyzed using t-test technique. Based on the results of the study showed that 11 study programs of the academic procrastination level of the students of the teaching and education faculty of the University of PGRI Palembang were in the high category with details of 10 courses in the high category and 1 study program in the medium category. Furthermore, the results of the hypothesis test showed that the level of academic procrastination of the students of the faculty of education and education at the PGRI University of Palembang, male and female, there were no significant differences. The results of this study can be used as a basis for providing services to students so that students no longer occur in completing studies.
\end{abstract}

\section{Citation Info}

Ramadhani, E., \& Putri, R.D., (2019). Students' academic procrastination in doing thesis. Biblio Couns: Jurnal Kajian Konseling dan Pendidikan, 2(03), 97-104. 


\section{INTRODUCTION}

Counseling is an assistance service by professionals to a person or group of individuals for the development of effective daily life and the handling of disrupted effective daily lives with an independent personal focus that is able to control itself through the implementation of various types of services and support activities in the learning process (Prayitno, 2013). Based on this understanding, it can be understood that someone who can be said to have a problem if his effective daily life is disrupted. In general, people in Indonesia can be sure to have problems, both economic, social, and other problems. Problems experienced by the people of Indonesia are usually resolved as a family, and it has become a tradition in the community. Family-wide problem solving can usually help or find a way out, but not a few problems the community does not find a way out. At present, the problems that occur in the community are very complex, especially the problems of students in carrying out lectures.

Students in an educational institution usually have a lot of activities to do. These activities are related to lectures and daily activities on campus and outside the campus. As a student, there must be many obstacles and problems while undergoing education in higher education. The problem that often occurs is the process of writing the final project or thesis. This problem usually starts when the final thesis is completed. Not a few students are late in their studies and exceed the time limit for recovery until there is a dropout. These problems usually have a negative impact on students, such as an obstruction in graduation and even lead to severe stress. Stress is making a negative thesis impact on student psychology, and it can cause students to think short by committing suicide. Not a few cases of student suicide caused by thesis, for example, a 23-year-old youth in the name of Marolop Marko Manurung, was found dead by hanging himself in his house. This case occurred because Marko was stressed in working on his thesis. The stress was caused by the frequency of Marko's thesis proposals being rejected by his mentor (Gunadha, 2018).

Based on the foregoing, students who have more than eight semesters of study period are indicated that students are negligent in the lecture process even negligent in completing their final or thesis work. The lecture process requires students to get a standardized value and even good grades for each course given. Students are expected to attend lectures well, including attending the lecture process, doing assignments well, being active in the lecture process, and even being able to explain lecture material well in front of students and lecturers to get good grades. Martin and Osborne (in Yulistia, 2008) explained that one of the characteristics of a successful student is a student who is able to manage and divide his time to work on college assignments. The ability to do this is not possessed by all students because most students are negligent and perform their duties as students.

Student negligence in the lecture process, if it continues to occur, then it will depend on the completion of the final project or thesis. Delays in carrying out these tasks are known as academic procrastination. Academic procrastination is a behavior that is not effective and efficient in utilizing time, and there is a tendency not to immediately start an action or postpone a task to be done until the next time so that the postponement behavior can hamper the academic success of the individual itself. Furthermore, Tuckman (1990: 3) explains, "Procrastination results from the combination of (1) disbelieving in one's own capability to perform a task, (2) being unable to postpone gratification, (3) assigning blame for one's own prediction to 
external sources". This means that the combination of procrastination is the ability of oneself to do the task, unable to delay and assign others to do the work.

The phenomenon of academic procrastination generally occurs because of the tendency of students to make delays in carrying out the tasks to be carried out. Ellis and Knaus (in Rumiani, 2006) revealed that almost $70 \%$ of students abroad did procrastination in the broadest sense. The phenomenon of academic procrastination above occurred in the Teaching and Education Faculty of the PGRI University of Palembang in doing thesis work. It can be seen from the period of study of students who are more than the limit or more than eight semesters. The study period of the faculty and teacher education students can be seen in the following table.

\begin{tabular}{llcc} 
No. & \multicolumn{2}{c}{ Table1. Average Student Study Period } \\
& & $\begin{array}{c}\text { Average study } \\
\text { period (years) }\end{array}$ & $\begin{array}{c}\text { Average graduate } \\
\text { cumulative } \\
\text { achievement index }\end{array}$ \\
\hline $\mathbf{1})$ & $(2)$ & $(3)$ & $(4)$ \\
\hline $\mathbf{1}$ & PS 1: Bahasa Inggris & 4,5 & 3,22 \\
\hline $\mathbf{2}$ & PS 2: Bahasa Indonesia & 4,4 & 3,19 \\
\hline $\mathbf{3}$ & PS.3: Matematika & 4,6 & 3,18 \\
\hline $\mathbf{4}$ & PS.4: Fisika & 4,6 & 3,23 \\
\hline $\mathbf{5}$ & PS.5: Sejarah & 4,2 & 3,22 \\
\hline $\mathbf{6}$ & PS.6: Akuntansi & 4,5 & 3,26 \\
\hline $\mathbf{7}$ & PS.7: Geografi & 4,5 & 3,26 \\
\hline $\mathbf{8}$ & PS.8: BimbinganKonseling & 4,5 & 3,23 \\
\hline $\mathbf{9}$ & PS.9: Olahraga & 4,6 & 3,29 \\
\hline $\mathbf{1 0}$ & PS.10: Sendratasik & 4,5 & 3,33 \\
\hline $\mathbf{1 1}$ & PS 11:PG-PAUD & $\mathbf{4 , 2}$ & 3,35 \\
\hline & Average in the Faculty & $\mathbf{4 , 4 6}$ & $\mathbf{3 , 1 4}$ \\
\hline
\end{tabular}

(Source, Quality Assurance Group in the faculty of education 2018)

Based on the acquisition of data in the academic section of Palembang PGRI University, there is an average of graduates of the teacher training and education faculty completing studies over four years, which is 4.46 years or are in the ninth semester.

Based on the above phenomena, it is indicated that the students of the teacher and education faculty of PGRI Palembang University experienced procrastination in working on their thesis. Furthermore, students' academic procrastination in working on their thesis can be seen from the fact that students have not yet done their thesis because they are busy repeating lectures that have not yet passed. Based on these phenomena, it can be said that students carry out academic procrastination not only in the completion of the thesis, but also delay in carrying out the recovery tasks they undergo. Problems experienced by students related to academic procrastination should be corrected or overcome. How to fix the problem can be given service assistance, especially by academic advisers, the head of the study program can even be given counseling services so that students can overcome the problem and avoid excessive stress.

Based on the description above, the researcher tries to uncover the level of student academic procrastination in working on the thesis. The data obtained will be a reference for related parties in helping to overcome the student's problem. Based on this, the researcher will examine in more depth with regard to the academic procrastination of students in working on their thesis. 


\section{METHODOLOGY}

The research design used in this study is a comparative descriptive study. According to Irawan (1996:60), descriptive research is research that aims to describe or explain things as they really are. This type of research that will be used is comparative descriptive research. Subana (2001: 89) states that research with descriptive format is research that aims to explain, summarize conditions with various situations, or various variables that arise in the community based on what they are in accordance with reality.

In connection with this Yusuf (2005: 82) that descriptive research is one type of research that aims to describe systematically, factually and accurately about the facts and nature of certain populations and try to describe the phenomenon in detail as it is, meaning descriptive research is research that is describe something that is happening as is. Furthermore, this research will also compare (comparative) regarding academic procrastination of students in doing thesis between men and women.

This research was conducted in the faculty of education and education at the University of PGRI Palembang in the class of 2013, 2014 and 2015. The population in this study were 224 students spread over 11 study programs. Furthermore, the sample redistribution in this study uses the proportional Random Sampling technique with the Slovin formula, as many as 144 students will be obtained as the research sample. The description of the data will be done using a percentage formula after determining the criteria for the level of student academic procrastination. After the decision is taken on the level of student academic procrastination, a hypothesis test will be conducted to distinguish the level of academic procrastination of the students of the teaching and education faculty in doing thesis work between men and women. Hypothesis testing in this study uses parametric analysis with t test, using SPSS version 20.00.

\section{RESEARCH RESULTS AND DISCUSSION}

\section{Research Results}

Based on the results of research that has been carried out, the following data are obtained.

Table 2. Number of Research Samples

\begin{tabular}{llcc} 
No. & \multicolumn{1}{c}{ Study program } & $\begin{array}{c}\text { Number of } \\
\text { Students }\end{array}$ & Percentage \\
\hline $\mathbf{( 1 )}$ & \multicolumn{1}{c}{$(\mathbf{2})$} & $\mathbf{( 3 )}$ & $\mathbf{( 4 )}$ \\
\hline $\mathbf{1}$ & PS 1: Bahasa Inggris & 17 & 11.8 \\
\hline $\mathbf{2}$ & PS 2: Bahasa Indonesia & 19 & 13.2 \\
\hline $\mathbf{3}$ & PS.3: Matematika & 12 & 8.3 \\
\hline $\mathbf{4}$ & PS.4: Fisika & 7 & 4.9 \\
\hline $\mathbf{5}$ & PS.5: Sejarah & 9 & 6.3 \\
\hline $\mathbf{6}$ & PS.6: Akuntansi & 10 & 6.9 \\
\hline $\mathbf{7}$ & PS.7: Geografi & 7 & 4.9 \\
\hline $\mathbf{8}$ & PS.8: BimbinganKonseling & 15 & 10.4 \\
$\mathbf{9}$ & PS.9: Olahraga & 24 & 16.7 \\
\hline $\mathbf{1 0}$ & PS.10: Sendratasik & 18 & 12.5 \\
\hline $\mathbf{1 1}$ & PS 11:PG-PAUD & 6 & 4.2 \\
\hline $\mathbf{1 2}$ & PS 12. PGSD & 0 & 0.0 \\
\hline & The amount in the Faculty & $\mathbf{1 4 4}$ & $\mathbf{1 0 0}$ \\
\hline
\end{tabular}


Based on the results of calculations using the percentage formula, the percentage is based on the study program being the research sample, namely; English for 17 people with a percentage of $11.8 \%$, Indonesian for 19 people with a percentage of $13.2 \%$, Mathematics for 12 people with a percentage of $8.3 \%$, Physics for 7 people with a percentage of $4.9 \%$, History of 9 people with a percentage of $6.3 \%$, Accounting for 10 people with a percentage of $6.9 \%$, Geography of 7 people with a percentage of $4.9 \%$, Counseling Guidance by 15 people with a percentage of $10.4 \%$, Sports by 24 people with a percentage of $16.7 \%$, Sendratasik as many as 18 people with a percentage of $12.5 \%$, PG-PAUD as many as 6 people with the percentage is $4.2 \%$ and the PGSD is 0\% because there are no 2013, 2014 and 2015 students.

\begin{tabular}{|c|c|c|}
\hline \multicolumn{3}{|c|}{ Respondent Data } \\
\hline Study program & Percentage & Category \\
\hline PS 1: Bahasa Inggris & 75.92 & High \\
\hline PS 2: Bahasa Indonesia & 74.21 & High \\
\hline PS.3: Matematika & 66.77 & Medium \\
\hline PS.4: Fisika & 80.27 & High \\
\hline PS.5: Sejarah & 73.40 & High \\
\hline PS.6: Akuntansi & 71.81 & High \\
\hline PS.7: Geografi & 78.93 & High \\
\hline PS.8: BimbinganKonseling & 70.54 & High \\
\hline PS.9: Olahraga & 74.71 & High \\
\hline PS.10: Sendratasik & 72.95 & High \\
\hline PS 11:PG-PAUD & 79.89 & High \\
\hline PS 12. PGSD & 0 & High \\
\hline Average & 74.54 & High \\
\hline
\end{tabular}

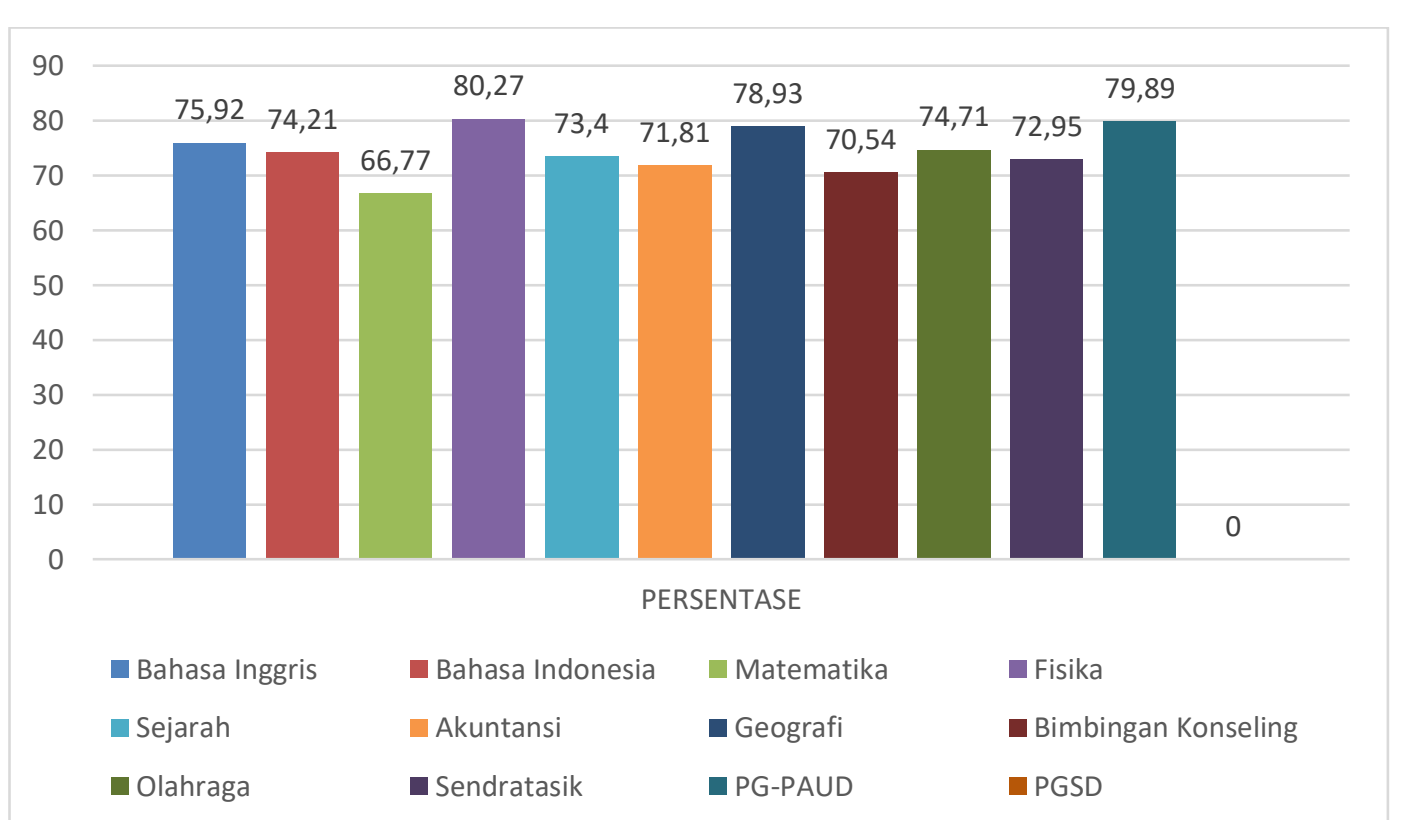

Picture1. Differences in Academic Procrastination Levels of Study Programs

Based on the results of research that has been conducted to 144 samples with the distribution of 11 study programs in the faculty of education and education at the University of PGRI Palembang, it is obtained that 10 study programs are in the high category, and 1 study program is in the medium category, namely the mathematics 
study program. The results of the acquisition of this data, on average, are in the high class, with a percentage of $74.54 \%$.

Based on the results of the analysis of the t-test analysis obtained academic procrastination data of students in doing the thesis with a sample of 70 women and 74 students. In the sample of female students, the mean score was 117.61, and in the sample of men, it was 118.85. Based on the results of the average score, data between men and women have a difference of 1.24 . It can be concluded that mathematically has a difference that is not too large. To see the extent of the difference, it is necessary to analyze the hypothesis test using t test. Furthermore, after data analysis is performed, sig. (2-tailed) of $0.557>0.05$ then Ho was accepted by $\mathrm{Ha}$ because there was no difference in the academic procrastination of the students of the teaching and education faculty at the PGRI University of Palembang in working on male and female gender thesis.

\section{DISCUSSION}

The findings of this study indicate that, in general, the level of academic procrastination of the faculty and teacher education students of the PGRI University of Palembang is in the high category. Based on the results of the study, as many as 10 study programs are in the high class, and 1 study program is in the medium category, namely the mathematics study program. Overall academic procrastination of the students of the teaching and education faculty at the PGRI Palembang University is in the high category with a percentage of $74.54 \%$.

This study aims to reveal the level of academic procrastination of the students of the teaching and education faculty at the PGRI University of Palembang in working on their thesis. The results of this study showed that in general, the 2013 and 2014 faculty and education faculty students experienced academic procrastination in doing thesis work. This decision can be concluded based on the results of the dissemination of instruments that have been carried out by researchers. This data consists of 11 study programs and 144 respondents consisting of 70 female students and 74 male students.

Tuckman (1990) explains, "Procrastination is attitudinally and behaviorally. "That is, procrastination is an attitude and behavior. The postponement attitudes and behavior of students when starting and doing assignments, which consist of individual assignments or group assignments given by the lecturer, with the habit, it has an impact on the delay in doing the final project or thesis. Delays in doing thesis will greatly affect the future of students and also negatively affect students, and students are often known as dysfunctional procrastination, i.e., if students postpone doing thesis work and do not have the desire to complete it. Delays are also positive or often known as functional procrastination, i.e., if a person makes a delay accompanied by a strong reason and has a definite goal so as to minimize losses even useful for making an effort so that the task can be completed well (Risnawita and Ghufron, 2014).

Based on the results of hypothesis testing that has been done, it can be concluded that there is no difference in the level of academic procrastination of male and female students. Academic procrastination is an act of delay in carrying out or doing tasks without a set time limit. Furthermore, Wolters (2003) revealed that "academic procrastination is a failure in doing academic work within the desired time frame or delaying doing work until the last moment. "Academic procrastination is understood as a behavior that becomes an ineffective habit and tends to be negative 
in procrastinating work. Prolonged procrastination can certainly disrupt individual activity and can psychologically disrupt individual conditions.

Based on this understanding, it can be understood that the act of delay in completing a task is a negative thing. These delays will affect the future of students, especially if these delays are related to doing the final project or thesis. The thesis is a work that needs to spend time, energy, thoughts and costs to complete it well if students have the nature of procrastinating in doing assignments, not a few students who are slow in completing their education could even result in the student's study period running out and will be dropped out

\section{CONCLUSION}

Based on the results of research that has been carried out in general, the level of academic procrastination of the faculty and teacher education students of the University of PGRI Palembang is in the high category. Furthermore, the results of the hypothesis test that has been done using the $t$ test then there is no significant difference in the level of academic procrastination of FKIP Palembang PGRI students between the sexes of men and women.

Based on the results of the research, discussion and conclusions that have been presented, there are a number of things that become researchers' suggestions that can be used as a follow up in this study, including; for the guidance and counseling service unit of the pgri university of Palembang, for the head of the study program and majors, for the dean and the rector and for other researchers.

\section{REFERENCES}

Gunadha. (2018). Skripsi Selalu Ditolak Dosen, Mahasiswa Gantung Diri. Suara.com. Diakses pada 23 Januari 2019. Tersedia [Online] https://www.suara.com/news/2018/11/23/143328/skripsi-selalu-ditolakdosen-mahasiswa-gantung-diri.

Irawan, P. (1996). Logika dan prosedur penelitian. Jakarta: STIA-LAN Press.

Prayitno. (2013). Konseling integritas. Padang: FIP UNP

Risnawita, R., \& Ghufron, M.N. (2014). Teori-teori psikologi. Jakarta: Ar-Ruzz Media.

Rumiani. 2006. Prokrastinasi akademik ditinjau dari motivasi berprestasi dan stres mahasiswa. Jurnal Psikologi Universitas Diponogoro. 3(2). 16-17.

Tuckman. (1990). Measuring procrastination attitudinally and behaviorally". Journal Procrastination Scale. Florida State University.

Wolters, C. A. (2003). Understanding procrastination from a selfregulated learning perspective. Journal of Educational Psychology, 95(1), 179-187.

Yulistia. (2008). Panduan bagi fasilitator PDPT OBM 2008. Diakses pada tanggal 15 Desember $2016 \quad$ [online] http://www.clr.ui.edu/wpcontent/uploads/2008/07/panduan-bagi-fasilitator.pdf. 
Biblio Couns : Jurnal Kajian Konseling dan Pendidikan | Vol. 2 No. 3 November 2019

Yusuf, A. M. (2005). Metodologi penelitian. Padang: UNP Press. 